\title{
MINERAL RESOURCE POTENTIAL \\ OF THE JAMES RIVER FACE WILDERNESS, BEDFORD AND ROCKBRIDGE COUNTIES, VIRGINIA
}

By

C. Ervin Brown ${ }^{1}$ and Gertrude C. Gazdik ${ }^{2}$

\section{STUDIES RELATED TO WILDERNESS}

Under the provisions of the Wilderness Act (Public Law 88-577, September 3, 1964) and the Joint Conference Report on Senate Bill 4, 88th Congress, the U.S. Geological Survey and the U.S. Bureau of Mines have been conducting mineral surveys of wilderness and primitive areas. Areas officially designated as "wilderness," "wild," or "canoe" when the act was passed were incorporated into the National Wilderness Preservation System, and some of them are presently being studied. The act provided that areas under consideration for wilderness designation should be studied for suitability for incorporation into the Wilderness System. The mineral surveys constitute one aspect of the suitability studies. The act directs that the results of such surveys are to be made available to the public and be submitted to the President and the Congress. This report discusses the results of a mineral survey of the James River Face Wilderness, Jefferson National Forest, Bedford and Rockbridge Counties, Virginia. The area was established as a wilderness by Public Law 93622, January 3, 1975.

\section{SUMMARY}

The rocks in the James River Face Wilderness are shales and quartzites that overlie a meta-igneous basement. They are folded into a large southwestward-plunging anticline that is cut off on the east and south by an extensive thrust fault that brings old basement rocks over the younger sedimentary rocks.

Geochemical studies of stream sediments, soils, and rocks do not reveal any unusually high metal concentrations, but a large resource of metallurgical-grade quartzite and shale suitable for structural clay products and lightweight aggregate is in the wilderness. Antietam (Erwin) Quartzite has been quarried at three sites in the wilderness as raw material for silicon used in the manufacture of ferrosilicon. Other uses included crushed rock for concrete aggregate, road metal, and railroad ballast, and sand for cement and mortar. Potential uses include ganister for silica brick and specialty sands such as filter and furnace sand. Firing tests on samples of shale from the Harpers (Hampton) Formation show that it could be used for the manufacture of brick and as lightweight aggregate. Of marginal economic interest are heavy-mineral layers in the basal Unicoi (Weverton) Formation.

\section{INTRODUCTION}

The James River Face Wilderness comprises about 8,800 acres $(3,561 \mathrm{ha})$ of steep-sloped land in the Jefferson National Forest, Bedford and Rockbridge Counties, Va. Mineral rights are privately owned on about 300 acres (121 ha).

${ }^{1}$ U.S. Geological Survey

${ }^{2}$ U.S. Bureau of Mines
The wilderness is bounded on the northeast by the James River where it flows eastward through the Blue Ridge (fig. 1). Part of the southern boundary of the wilderness is coincident with the boundary of the Blue Ridge Parkway, and part of the southwestern boundary is along State Route 781, a gravel mountain road that extends southeast from Arnold Valley to a junction with the Blue Ridge Parkway at Petites Gap. The area is $18.5 \mathrm{mi}(30 \mathrm{~km})$ northwest of Lynchburg and about $16 \mathrm{mi}(25 \mathrm{~km})$ south of Lexington, Va.

Several trails including the Appalachian Trail traverse the wilderness. A 7-mi $(11-\mathrm{km})$ bridal path heads at Sulphur Spring and comes to a cul-de-sac on the mountain divide. The steep, north-facing part of the wilderness, the James River face, is trailless and is most easily reached by canoe.

\section{PREVIOUS STUDIES}

Bloomer and Werner (1955) included the wilderness in a study of the Blue Ridge of central Virginia. Their map, at a scale of $2 \mathrm{mi}$ to the inch, shows the essential features of the geologic structure of this area. Earlier works covering areas close to the wilderness are studies by J. L. Campbell (1880, $1882)$ and H. D. Campbell (1885). These reports deal with the basic stratigraphy and structure and are remarkably perceptive of the geological situation as known today. Spencer (1968) published detailed maps of the geology west of and adjacent to the wilderness. Many other studies pertinent to the understanding of rock units within the area are referenced by Bloomer and Werner (1955).

\section{PRESENT STUDY}

This study was undertaken by the U.S. Geological Survey (USGS) and the U.S. Bureau of Mines (USBM) to appraise the mineral resource potential of the wilderness.

The geologic map (Brown and Spencer, 1981) is the result of an informal cooperative effort between the geology department of Washington and Lee University and the USGS. Most of the geologic mapping was done by E. W. Spencer and students of Washington and Lee University from 1970 to 1980 as part of Spencer's continuing program of mapping nearby quadrangles in Virginia (Spencer, 1968). C. E. Brown, who was assisted at various times by D. B. Tatlock, David McQueen and A. E. Grosz during short field seasons in the autumn of 1978 and spring and autumn of 1979 , collected geochemical samples from the wilderness and vicinity and did some geologic mapping, particularly in the James River Gorge and the Big Cove Branch area.

Geochemical samples consisting of 63 streamsediment, 45 soil, and 45 rock, were analyzed in USGS laboratories by means of semiquantitative spectrographic methods for 31 elements and by atomic absorption for gold and zinc. The data and an interpretation are included in the report by C. E. Brown and D. F. Siems (1982). 


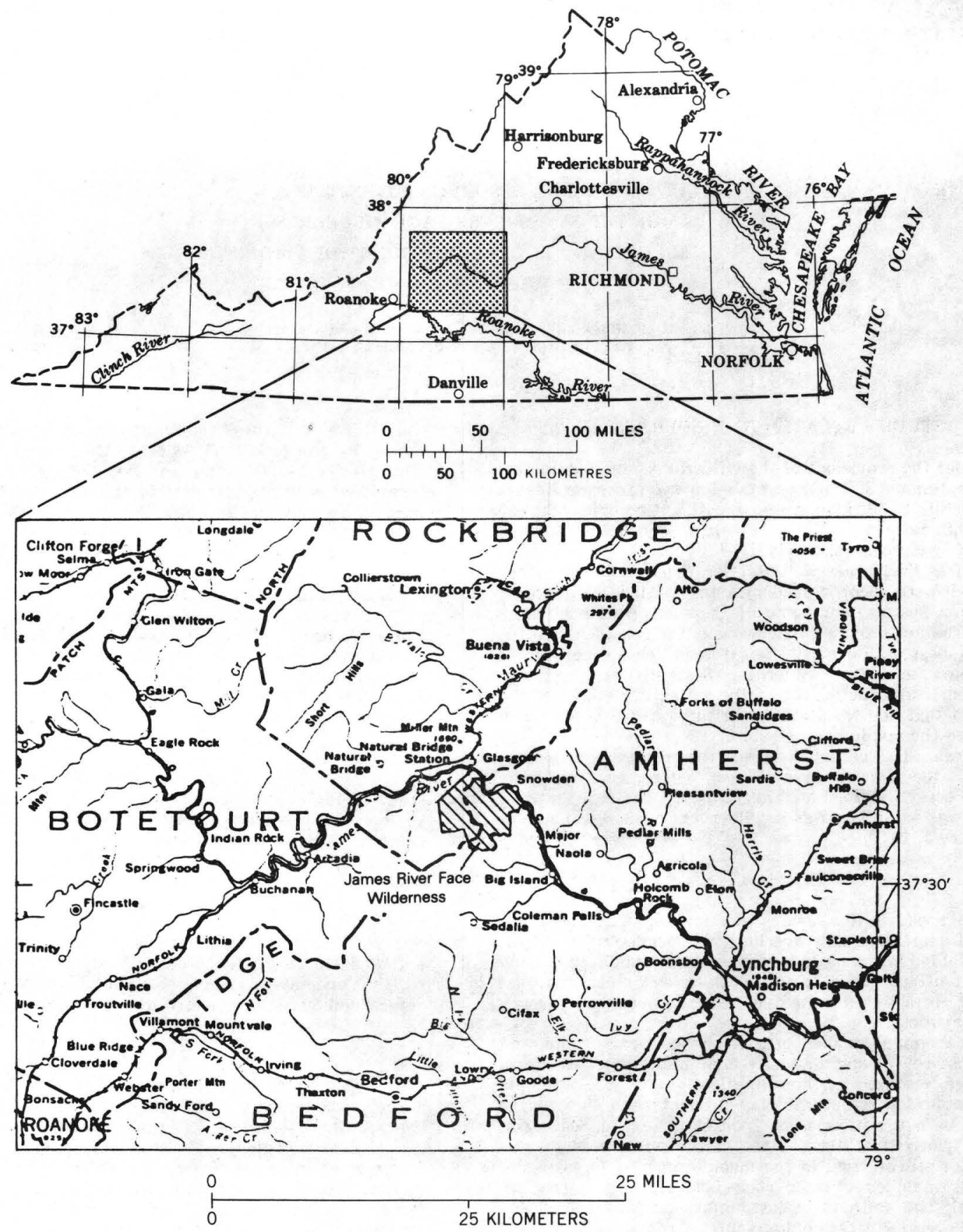

Figure 1.-Location of James River Face Wilderness. 
An investigation of past mining activity in the area and sampling of rocks for testing of their possible utilization for various mineral products was done by R. B. Ross, Jr. and G. C. Gazdik of the USBM in the spring of 1980 (Gazdik and Ross, 1982). Twenty rock samples and four pannedconcentrate samples were collected during the investigation. All samples were analyzed spectrographically for 40 elements by TSL Laboratories, Ltd., Opportunity, Wash. Shale samples were evaluated for ceramic and bloating properties by the USBM Tuscaloosa Research Center, Tuscaloosa, Ala.

\section{SURFACE- AND MINERAL-RIGHTS OWNERSHIP}

The Federal Government owns all surface rights in the wilderness and all mineral rights except those on about 300 acres (121 ha) along the James River in the extreme eastern part of the wilderness (fig. 2).

\section{ACKNOWLEDGMENTS}

We sincerely appreciate the cooperation of Dr. Edgar W. Spencer of Washington and Lee University for supplying much of the detailed geologic data for the wilderness. He and students have mapped geologic quadrangles adjacent on the west (Spencer, 1968) and now are completing the Snowden $71 / 2$-minute quadrangle that includes the wilderness. Spencer is the foremost authority on the geology of that area and his generosity has enabled us to know the distribution of rock units much better than the allotted field time could have allowed.

\section{GEOLOGY AND GEOCHEMISTRY}

Rocks of the James River Face Wilderness are clastic rocks of the Chilhowee Group of Early Cambrian and Early Cambrian(?) age that rest unconformably on a basement composed of orthogneisses and igneous intrusive rocks of Proterozoic age (Brown and Spencer, 1981). The gneiss is mainly garnetiferous hypersthene granodiorite that is retrograded by greenschist facies metamorphism. Intruding the gneiss are coarse-grained dioritic "porphyry" bodies and narrow, fine-grained mafic dikes also of Proterozoic age. The overlying Chilhowee Group comprises in ascending order the Unicoi (Weverton) Formation made up of interlayered quartzite, graywacke, pebbly quartzite, shale, and tuffaceous rock; the Harpers (Hampton) Formation that is mostly darkgray shale and includes discontinuous quartzite units; and the Antietam (Erwin) Quartzite composed of a vitreous bluishgray orthoquartzite that weathers to buff-colored sandstone.

The rocks in the study area and vicinity are folded and form a broad southwest-plunging anticline. The southeast limb of the fold is interrupted by a steeply dipping fault that brings the Harpers (Hampton) Formation down against older beds of the Unicoi (Weverton) Formation. Where the fault crosses the James River, rocks of the Harpers (Hampton) Formation are faulted against gneisses of Proterozoic age. Minor folding in the northwest limb of the broad anticline consists of gentle, step-like monoclines that are exemplified in the quartzite units along the James River. In contrast, the folding in the Harpers (Hampton) and Unicoi (Weverton) Formations southeast of the fault that cuts out the southeast limb of the anticline is more compressed and is overturned to the northwest, producing a predominance of southeast dips. The fault that cuts out the southeast limb of the anticline has been traced southwest of the James River for $3 \mathrm{mi}(5 \mathrm{~km})$, where it is lost in the shales of the Harpers (Hampton) Formation. The shale units all show a well-developed slaty cleavage that has a moderate southeast dip.

A major thrust sheet that is part of a system of thrust faults throughout the Blue Ridge extends east-west across the southern part of the wilderness. It cuts off the broad, plunging anticline and has placed gneisses of Proterozoic age across the southern part of the area (Brown and Spencer, 1981).
A reconnaissance geochemical survey of the James River Face Wilderness was made by the USGS to test for unidentified and (or) unexposed mineral deposits that might be recognized by their geochemical halos. Several samples of limonite-mineralized rock have detectable gold and contain a low level of cobalt. Saussuritized dioritic "porphyry" bodies in the basement rocks consistently have a moderately high zinc content; one sample also contains detectable silver. However, the samples either do not represent a large quantity of rock or the metals are not in sufficiently high concentrations to indicate economic significance.

The only mineral occurrences that may be of marginal economic interest are heavy-mineral layers in the basal Unicoi (Weverton) Formation. These are genetically similar to much younger unconsolidated, black-sand deposits being mined elsewhere in the United States for ilmenite and zircon. Because the Unicoi-hosted black sands are included in quartzite, they would be very difficult to mill. Unless ilmenite were found in much higher concentrations or volumes than seen here, these black sands are of no economic value.

\section{MINING AND PROSPECTING}

Harpers (Hampton) Formation and Antietam (Erwin) Quartzite are or have been the source locally of raw materials for the processing of lightweight aggregate, and for brickmaking, ferrosilicon, and ochre. Limonite in residual soil was mined within a mile of the wilderness for making iron.

Lightweight aggregate is produced from Harpers (Hampton) Formation shale from two quarries $3 \mathrm{mi}(5 \mathrm{~km})$ northeast of the wilderness (Gazdik and Ross, 1982). Expanded aggregate is made in a plant adjacent to the quarries by bloating the shale in rotary kilns. Production is substantial and the plant and quarries have been active since the mid-1960s.

A quarry recently was opened in weathered Harpers (Hampton) Formation shale about $1500 \mathrm{ft}(460 \mathrm{~m})$ north of the wilderness on the north side of the James River. The weathered shale is used for making bricks at kilns located near Natural Bridge Station, about $1.5 \mathrm{mi}(2.4 \mathrm{~km})$ northwest of the wilderness.

From 1880 to 1904 , superior-grade roofing slate was quarried from the Harpers (Hampton) Formation by the Virginia Slate Mining Co. about $3.5 \mathrm{mi}(5.6 \mathrm{~km})$ northeast of the wilderness.

Metallurgical-grade Antietam (Erwin) Quartzite was produced from 1945 to about 1966 from three quarries in the wilderness. The quartzite was crushed locally and shipped to a plant in West Virginia for use in the production of ferrosilicon (Lowry, 1954). Other products from the crushing plant included crushed stone for concrete aggregate, road metal, and railroad ballast, and sand for cement and mortar.

Bedded iron deposits in hematite-rich quartzite and quartz sandstones of the Harpers (Hampton) and Unicoi (Weverton) Formations have been mined or prospected near the wilderness (Woodward, 1936). Campbell (1882) described a small mine in a hematitic sandstone of the Unicoi (Weverton) Formation on the west side of Arnold Valley, 1.25 $\mathrm{mi}(2.0 \mathrm{~km})$ west of the wilderness. A bed of ferruginous quartzite in the Harpers (Hampton) Formation was located in the wilderness by the trail about $1000 \mathrm{ft}(305 \mathrm{~m})$ north of Sulphur Spring. Analyses of a sample show that it is less than 13 percent iron, too lean to have economic significance.

\section{ASSESSMENT OF MINERAL RESOURCE POTENTIAL}

Metallurgical-grade quartzite from the Antietam (Erwin) Quartzite and shale from the Harpers (Hampton) Formation that is potentially useful for lightweight aggregate and structural clay products are the principal mineral resources of the wilderness.

A large area of the wilderness is underlain by potentially valuable shale (fig. 3 ). Preliminary ceramic tests 


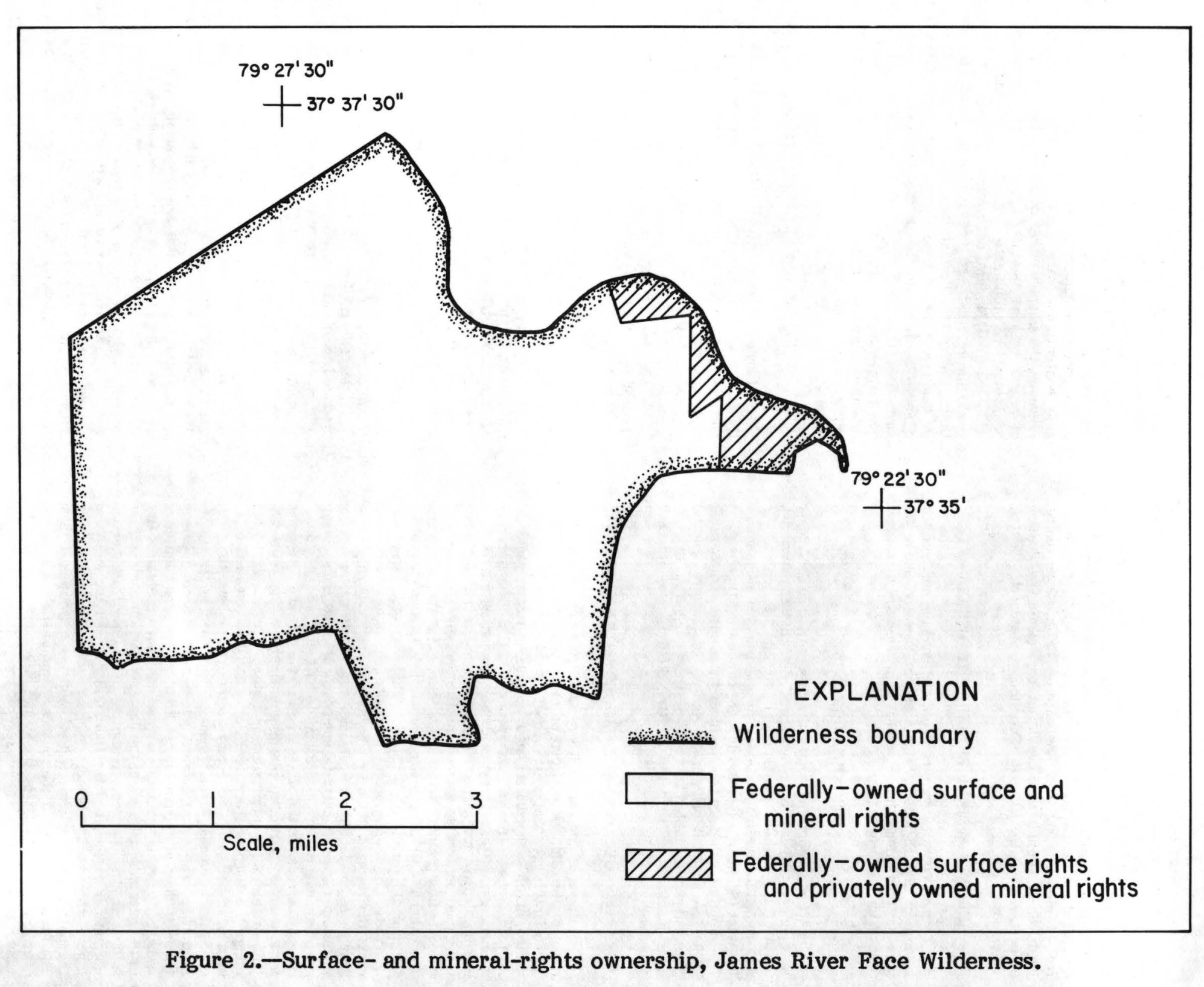




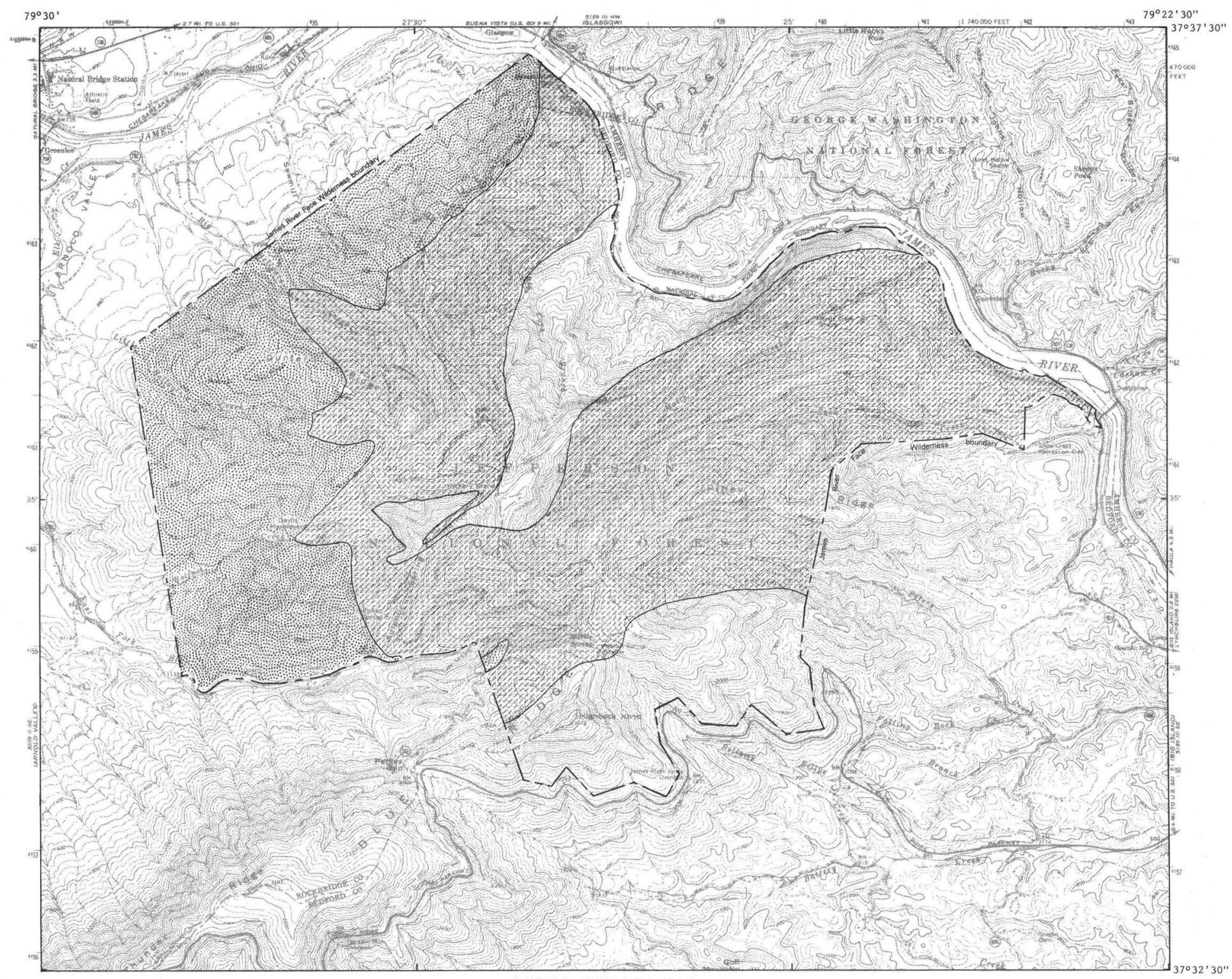

EXPLANATION

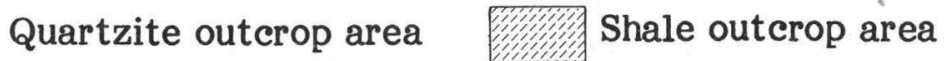

Figure 3.--Areas of shale and quartzite resources in the James River Face Wilderness. 
indicate that 4 of the 6 samples of Harpers (Hampton) Formation shale taken from scattered sites in and adjacent to the wilderness are suitable for structural clay products such as bricks and floor tile. One sample bloated during quick-fire testing, indicating suitability for lightweight aggregate (Gazdik and Ross, 1982).

Large resources of Antietam (Erwin) Quartzite of metallurgical grade are present in the wilderness (fig. 3). Currently, demand in this country for metallurgical-grade quartzite for ferrosilicon has been greatly curtailed because of imports of silicon-steel to American markets and the subsequent decline in production of this specialty steel by American companies (Gazdik and Ross, 1982).

Antietam (Erwin) Quartzite is additionally a potential source of ganister for silica brick, and for specialty sands such as filter and furnace sand. By-products from past crushing-plant operations have included crushed stone for concrete aggregate, road metal, and railroad ballast, and sand for use in cement and mortar. Antietam (Erwin) Quartzite does not meet the stringent physical requirements for highquality glass sand.

\section{OIL AND GAS POTENTIAL}

Rocks of the wilderness are not suitable as reservoirs for oil and gas because they are metamorphosed and porosity is low. These rocks, however, are part of the large eastern overthrust system (Milici, 1980), and thus at some speculative depth below a detachment zone rocks exist that might contain oil and gas. Leonard Harris (USGS, oral commun., 1981) estimates that in this area the detachment zone is 10,000 to $15,000 \mathrm{ft}(3000$ to $4600 \mathrm{~m})$ deep.

\section{REFERENCES CITED}

Bloomer, R. O., and Werner, H. J., 1955, Geology of the Blue Ridge region in central Virginia: Geological Society of America Bulletin, v. 66, no. 5, p. 579-606.

Brown, C. E., and Siems, D. F., 1982, Geochemical survey of the James River Face Wilderness, Bedford and Rockbridge Counties, Virginia: U.S. Geological Survey Miscellaneous Field Studies Map MF-1337-B.

Brown, C. E., and Spencer, E. W., 1981, Geologic map of the James River Face Wilderness, Bedford and Rockbridge Counties, Virginia: U.S. Geological Survey Miscellaneous Field Studies Map MF-1337-A, scale $1: 24,000$.

Campbell, H. D., 1885, The Potsdam group east of the Blue Ridge at Balcony Falls, Virginia: American Journal of Science, 3rd series, v. 29, p. 470-474.

1882, Geology and mineral resources of the James River Valley, Virginia: New York, G. P. Putnam's Sons, $119 \mathrm{p}$.

Campbell, J. L., 1880, The geology of the Blue Ridge, etc., at James River Gap, Virginia: The Virginias, published by Jed. Hotchkiss, Staunton, Virginia. v. 1 , no. 6 , p. $86-$ $87,94$.

Gazdik, G. C., and Ross, R. B., Jr., 1982, Map showing quarries, mines, prospects, and sample data in and near the James River Face Wilderness, Bedford and Rockbridge Counties, Virginia: U. S. Geological Survey Miscellaneous Field Studies Map MF-1337-C .

Lowry, W. D., 1954, Silica sand resources of western Virginia: Virginia Polytechnic Institute Bulletin, Engineering Experiment Station Series no. 96, 63 p.

Milici, R. C., 1980, Relationships of regional structure to oil and gas producing areas in the Appalachian basin: U.S. Geological Survey Miscellaneous Investigations Map I917-F, 5 sheets.

Spencer, E. W., 1968, Geology of the Natural Bridge, Sugarloaf Mountain, Buchanan, and Arnold Valley quadrangles, Virginia: Virginia Division of Mineral Resources Report of Investigations 13, 55 p.

Woodward, H. P., 1936, Geology and mineral resources of the Natural Bridge region: Unpublished report, Virginia Division of Mineral Resources, Charlottesville, Va. 